\title{
Anti-Crisis Financial and Personnel Management as Key Factors to Provide Effective Development of Eastern European Enterprises in the Agricultural Sector
}

\author{
Submitted 11/05/20, $1^{\text {st }}$ revision 10/06/20, $2^{\text {nd }}$ revision $23 / 07 / 20$, accepted $30 / 07 / 20$ \\ Maxim V. Khatser ${ }^{1}$, Yuliia A. Perehuda ${ }^{2}$, Tatiana M. Korpaniuk ${ }^{3}$, \\ Khrystyna S. Stoliaruk ${ }^{4}$, Irina M. Yepifanova ${ }^{5}$, Oleksandr O. Shpynkovskyi ${ }^{6}$
}

\begin{abstract}
:
Purpose: The main aim of this research is the development of ways to enhance the efficiency and performance of anti-crisis financial and personnel management at Eastern European agricultural enterprises based on the assessment of the role of such management types and the determination of a set of problems from their implementation.

Design/Methodology/Approach: The study has used quantitative analysis, the method of forecasting time series based on the implementation of the regression function, as well as panel data to both estimate anti-crisis financial and personnel management in the agricultural sector of Eastern European countries and find problems in its application.

Findings: The study has proved the increase of the role of the agricultural sector in economies of Eastern European countries as well as a significant negative impact of unprofitable agricultural enterprises on it. Besides, the implementation of anti-crisis financial and personnel management in such enterprises and its key problems have been assessed.

Practical Implications: The study is important in terms of decreasing a share of unprofitable agricultural enterprises and accelerating the development of the agricultural sector in Eastern European Post-Soviet economies.

Originality/Value: The study has developed a set of ways to increase the efficiency and performance of the implementation and application of anti-crisis financial and personnel management in the agricultural sector of Eastern European countries.
\end{abstract}

\footnotetext{
${ }^{1}$ Associate Professor, Zaporizhzhia National University, Zaporizhzhia, 69600, Ukraine, E-mail: max.kh@ukr.net

${ }^{2}$ Associate Professor, Interregional Academy of Personnel Management, Kyiv, 02000,

Ukraine, E-mail: julilla.pereguda@gmail.com

${ }^{3}$ Associate Professor, Vinnytsia National Agrarian University, Vinnytsia, 21000, Ukraine,

E-mail: tsharko@ukr.net

${ }^{4}$ Associate Professor, Kyiv National Economic University named after Vadym Hetman, Kyiv, 03057,Ukraine, E-mail: kristina_stolyaruk@ukr.net

${ }^{5}$ Associate Professor, Odessa National Polytechnic University, Odesa, 65044, Ukraine,

E-mail: epifodessa@gmail.com

${ }^{6}$ Odessa National Polytechnic University, Odesa, 65044, Ukraine,

E-mail: shpinkovskiya@gmail.com
} 
Keywords: Agricultural enterprises, agricultural sector of economy, anti-crisis personnel management, anti-crisis financial management, Eastern European countries.

JEL Codes: Q10, M11, M12.

Article Type: Research paper.

\section{Introduction}

The transformation of economic systems of Eastern European countries is resulting in the search for new ways to provide long-term development, where one of the main ways is the production intensification and export of agricultural goods (Petrick and Weingarten, 2004). The increase in the role and impact of the agricultural sector on countries' economies, which were a part of the Soviet Union, is specifically happening nowadays (FAO, 2018; Shashyna, Zakharchenko, Darushyn, Buryk and Shpinkovska, 2018). The agricultural sector of these countries suffers less from the impact of negative factors; and in addition, it has a high sustainability level to crisis manifestations in both national and world economic systems. Besides, the study has determined the considerable competitiveness level of Eastern European manufacturers' agricultural goods against both the increasing demand for such goods and global climate changes (Kimhi and Lerman, 2015; Zakharchenko, Eremina, Ushakov, Odintson and Mylnichenko, 2019).

Despite the considerable positive moments in the development of the agricultural sector of Eastern European countries, which were a part of the Soviet Union, (growth in the amount of investment, the rapid updating of main funds, development and implementation of innovation, the quality increase in training and competitiveness of personnel), it is necessary to state that its potential is not used fully due to the operation of a great number of unprofitable enterprises that experience a financial crisis in the market (Chryniewicz, Kyryliuk and Wojtaszek, 2016; FAO, 2019). The study has outlined the critical need to decrease the amount of unprofitable agricultural enterprises in Eastern European countries from the Post-Soviet area in the context of providing development of both agricultural sphere and national economies in general. The stated above demands the implementation or the performance increase of anti-crisis financial management (ACFM) and anti-crisis personnel management (ACPM) at such economic entities.

The situation stated above needs considerable scientific research in this area. It is explained by the fact that now all scientific works that exist:

- are related to the study of the agricultural sector and its problems in Eastern European countries without the emphasis on the disclosure of problems on 
the implementation or increase of anti-crisis financial and personnel management performance among agricultural manufacturers in Eastern Europe (Batorski, 2011; Csáki, Kray and Zorya, 2006; Shashyna et al., 2018);

- dwell on problems of fighting against crises at the macro-level (world, international, and national economic systems) or micro-level (particular sectors/spheres of national economic systems or certain enterprises) without taking into consideration peculiarities of either agricultural sector or agricultural manufacturers from Eastern European countries (Bahadir, Unlu and Kapucu, 2008; Batorski, 2011; Gurtner, 2010; Zhigang and Hongqi, 2015);

- address the issues of anti-crisis financial and personnel management at Eastern European agricultural enterprises by emphasizing the role of certain countries and not considering general peculiarities for such countries (Dudareve, 2017; Narkevich, 2017; Usikova, 2019).

Taking into account the problems outlined above, the aim of the study is to develop ways to increase the effectiveness and performance of anti-crisis financial and personnel management at Eastern European agricultural enterprises based on the assessment of the anti-crisis financial and personnel management role and the determination of a set of problems of its implementation for such economic entities. Based on the aim of the study, it is important to prove or disprove a number of hypothesis, namely:

- the agricultural sector plays an essential role and takes a significant place in the economic systems of Eastern European countries that were a part of the Soviet Union;

- unprofitable enterprises do not have a great impact on the development of the agricultural sector and economies of Eastern European countries from the Post-Soviet space;

- anti-crisis financial and personnel management is implemented and used by a minor number of agricultural manufacturers from Eastern European countries that were a part of the Soviet Union and have a great number of general problems for all agricultural enterprises of these countries, where the key ones are personnel management (training) problems;

- Eastern European agricultural enterprises from the Post-Soviet space need the development and implementation of ways to increase the effectiveness and performance of ACFM and ACPM within the introduction of their stable long-term development.

\section{Materials and Methods}

The study has used quantitative analysis of statistic data, the method of forecasting time series based on the implementation of the regression function, as well as panel 
data to both estimate anti-crisis financial and personnel management in the agricultural sector of Eastern European countries and find problems in its application.

The methodology of the study is based on the system and functional, historical and system approaches in the revealing and solving problems on efficiency and performance enhancing of ACFM and ACPM at the agricultural enterprises in the Eastern European countries from the Post-Soviet space (Bański, 2018).

The work presents anti-crisis financial and personnel management as key factors to provide the development of Eastern European agricultural manufacturers. The research is based on the assumption that Eastern European agricultural enterprises from the Post-Soviet economies need the identification and elimination of ACFM and ACPM problems.

\section{Results}

\subsection{The Agricultural Sector and its Role in the Economic Systems of Eastern European Countries}

The complexity of transformation processes in economies of Post-Soviet countries in the Eastern Europe and the reluctance of the majority of enterprises from such countries to the competitive fight in terms of market economy functioning led to changes in key spheres of their economic systems, where agriculture took an important place (FAO, 2018; Shashyna et al., 2018; Zakharchenko et al., 2019). Furthermore, crises at the world, international, and national levels were increasing the role of agricultural production in Eastern European economies.

Under these terms, it is appropriate to study and prove the data given above based on the analysis of agricultural production in GDP of countries, which are related to the Eastern European countries from the Post-Soviet space (Ukraine, Russia, Belarus, and Moldova) during 2008 - 2019 (Figure 1). Concerning Ukraine, a number of tendencies are clearly detected in terms of the role of the agricultural sector in the economy of the country (Figure 1): a positive tendency of the agricultural production share in the national economic system during the entire period of the study $(+2.5 \%$ of country's GDP); a rapid growth of the agriculture share during the crises (20092011, 2015-2016); a big part of the agricultural sector in the country's economy during the entire period of the research, what is considerably higher than in developed countries or countries that are developing with high incomes (Lerman, 2009).

During the research period, the Russian agricultural sector demonstrated a stable development within 3-4 \% of the country's GDP (Figure 1). Meanwhile, similar to Ukraine, there is a clear tendency of its role increase under the crisis in the national economy. Relatively low values of the agricultural production share in the economy 
of Russia (at the level of developed countries or countries that are developing with high incomes) are related to the emphasis of the development of the country's economic system on mining operations, mainly oil and gas, as well as complex climate conditions for the agriculture development.

Figure 1. The share of agricultural sector in Eastern European economies of the Post-Soviet countries in 2008-2019, \% of GDP*

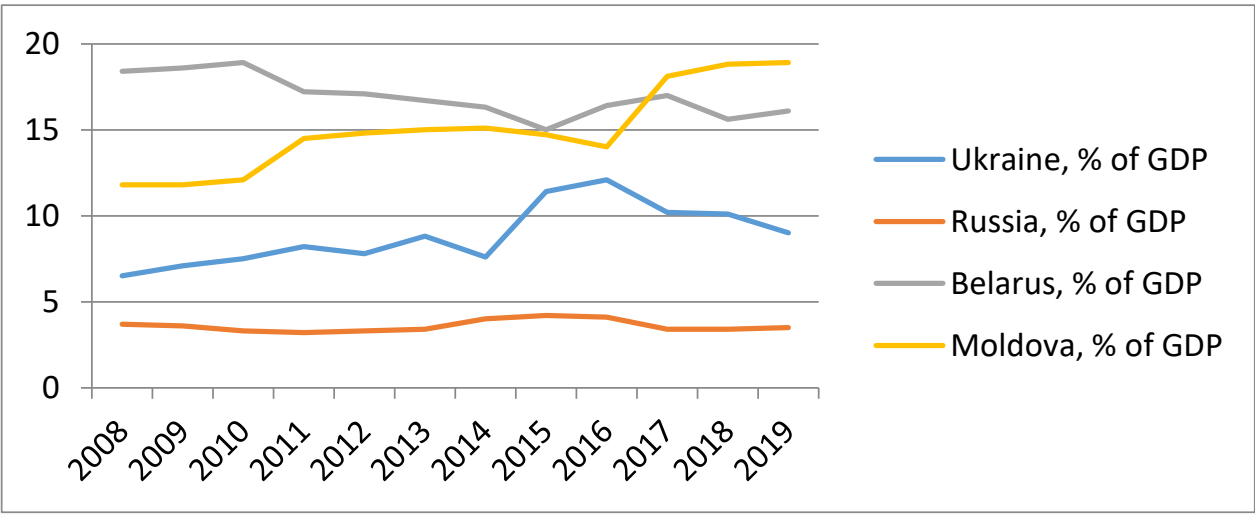

Source: * - developed by the author based on the sources (Federal State Statistic Service of the Russian Federation, 2020; National Bureau of Statistics of the Republic of Moldova, 2020; National Statistical Committee of the Republic of Belarus, 2020; State Statistics Service of Ukraine, 2020).

Belarus is the only country among those chosen for the research that demonstrated a negative tendency regarding the role of agricultural production in the economy $(-2.3$ $\%$ of the country's GDP). At the same time, Belarus repeats fully other tendencies that have been noted regarding Ukraine. Special attention is drawn to the critically important role of agricultural production for the country's economic system because it varied within 15-19\% of GDP during the entire period of the research.

The rapid growth of agricultural share in GDP of Moldova during the research period $(+7.1 \%$ of the country's GDP) has been observed. In addition, the study has identified its largest share in the national economy among all countries chosen for the analysis in 2019 (18.9\% of GDP). It has been underlined that all tendencies identified in the agricultural sector of Ukrainian and Belarusian economies are completely repeated in Moldova. Besides, the study has identified the critical importance of agricultural production for Moldova's economic system.

Thus, we can state that agricultural production plays an important role in the economies of Eastern European countries in the Post-Soviet area, where it is crucial for Ukraine, Belarus, and Moldova.

\subsection{The Impact of Unprofitable Enterprises on the Development of the Agricultural Sector and Economy of Eastern European Countries}


For agricultural production and economic systems of Eastern European countries in the Post-Soviet space, the important aspect is the availability of unprofitable enterprises in the agricultural sector. Trace their share dynamics in Figure 2.

Figure 2. Unprofitable agricultural enterprises' share in the Post-Soviet countries of Eastern Europe in 2008-2019, \% of the total number in the sector*

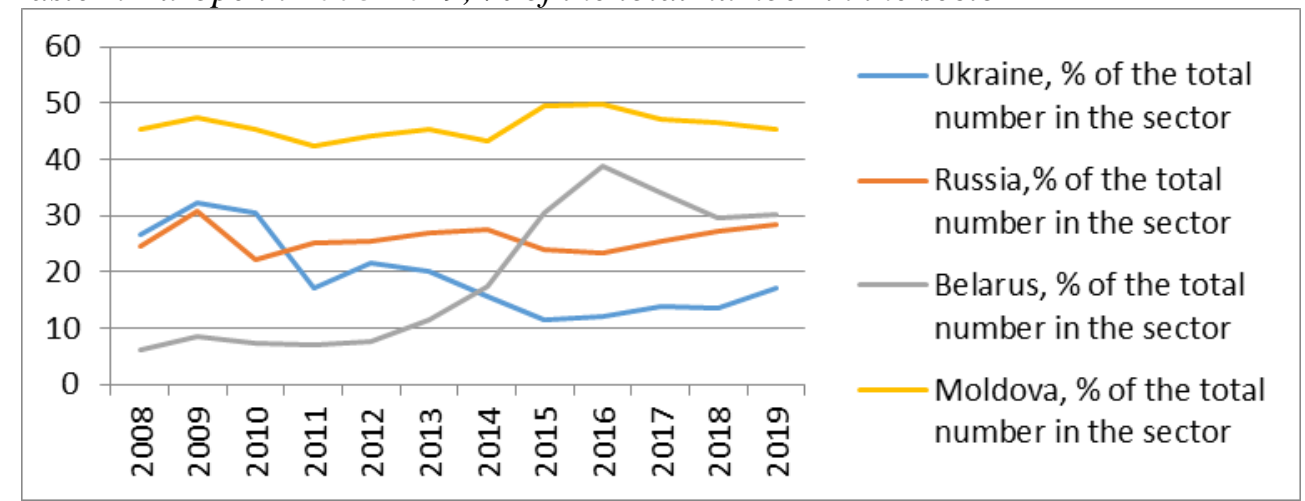

Source: * - developed by the author based on the sources (Federal State Statistic Service of the Russian Federation, 2020; National Bureau of Statistics of the Republic of Moldova, 2020; National Statistical Committee of the Republic of Belarus, 2020; State Statistics Service of Ukraine, 2020).

The assessment of unprofitable agricultural enterprises' share in the countries chosen for the study during 2008-2019 enables to detect such tendencies:

- all countries had a high level of unprofitable enterprises share in the agricultural sector. It is crucially important for Russia, Moldova, and Belarus;

- only Ukraine had a negative trend of changes in unprofitable enterprises' share during the research period. It was neutral for Moldova, and positive for Russia and Belarus, in particular;

- it has been identified that during crises a share of unprofitable enterprises was growing only in Belarus and Moldova, while in Ukraine and Russia it was declining;

- unprofitable enterprises have a significant impact on the development of the agricultural sector. Besides, they influence crucially the development of economies of countries chosen for the study by being one of the key destimulating factors.

Taking into consideration the data provided above, it is appropriate to make a threeyear forecast of changes of unprofitable agricultural enterprises' share in the PostSoviet countries of Eastern Europe (Table 1) based on the regression analysis, program possibilities of a computer program Stata 7.0, and the methodology developed by a group of scientists (Kalinichenko, Shmygol and Kostoglod, 2010), where the coefficient of determination $\left(\mathrm{R}^{2}\right)$ will be taken as an element for selecting 
the regression function to forecast. For every country chosen for the forecast, five regression functions were calculated. They included: linear, exponential, polynominal, logarithmic, and degree one. Then, the study selected the function, a coefficient of determination of which was maximally close to one.

Table 1. The value of regression function, coefficients of determination and the trend's direction within a three-year forecast of dynamics of unprofitable agricultural enterprises' share in the Post-Soviet countries of Eastern Europe

\begin{tabular}{|l|l|c|l|}
\hline Countries & Values of regression function & $\begin{array}{c}\text { The value of } \\
\text { coefficient of } \\
\text { determination }\left(\mathbf{R}^{\mathbf{2}}\right)\end{array}$ & $\begin{array}{c}\text { Trend's } \\
\text { direction }\end{array}$ \\
\hline Ukraine & Linear: $\mathrm{y}=2,672 \mathrm{x}+56,02$ & 0.9211 & Positive \\
\hline Russia & Exponential: $\mathrm{y}=39,161 \mathrm{e}^{0,046 \mathrm{x}}$ & 0.9307 & Positive \\
\hline Belarus & $\begin{array}{l}\text { Polynominal: } \\
\mathrm{y}=-0,036 \mathrm{x}^{2}+1,9423 \mathrm{x}+1,987\end{array}$ & 0.9514 & Positive \\
\hline Moldova & Exponential: $\mathrm{y}=28,38 \mathrm{e}^{0,069 \mathrm{x}}$ & 0.9033 & Positive \\
\hline
\end{tabular}

Source: Developed by the authors.

The study emphasizes that three-year forecasts have shown the availability of positive trends in the share's increase of unprofitable agricultural enterprises in the Post-Soviet Eastern European countries. The information provided above allows drawing the conclusion that Ukraine, Russia, Belarus and Moldova will experience the critically high negative impact of this factor on their own agricultural spheres and national economic systems without the implementation of changes.

\subsection{The Assessment of Anti-crisis Financial and Personnel Management in the Agricultural Sector of Eastern European Countries and Problems of its Implementation}

Taking into consideration the problems detected in the study and a negative impact of unprofitable agricultural enterprises on the agricultural sector and economic systems in general of Eastern European countries in the Post-Soviet space, economic entities need the implementation and activation of the implementation of anti-crisis financial (ACFM) and personnel (ACPM) management. At the same time, permanent tendencies of the quantity increase of unprofitable agricultural enterprises in the countries chosen for the research during 2008-2019 indicate the significant problems of the implementation and application of ACFM and ACPM. It demands their assessment (Table 2). To assess, the survey was conducted at thirty enterprises (10 big, 10 medium, and 10 small) that operated both at a loss and profitably for each country selected for the study.

Thus, based on the results of the survey, the study has identified that both profitable and unprofitable Eastern European agricultural manufacturers use anti-crisis financial and personnel management rather poorly. At the same time, elements (tools) of such types of management are implemented more actively in their 
management operation, especially at unprofitable economic entities. At the same time, there is a clear tendency of weak attention to ACFM and ACPM paid by MSE, especially by small enterprises.

Table 2. The assessment of the implementation and application of ACFM and ACPM at agricultural enterprises in Eastern European countries

\begin{tabular}{|c|c|c|c|c|c|c|}
\hline \multirow{2}{*}{ Question } & \multicolumn{3}{|c|}{ Profitable enterprises } & \multicolumn{3}{|c|}{ Unprofitable enterprises } \\
\hline & Big & Medium & Small & Big & Medium & Small \\
\hline $\begin{array}{l}\text { Does an } \\
\text { enterprise use } \\
\text { ACFM }\end{array}$ & $\begin{array}{l}\text { Yes (3); } \\
\text { No (37) }\end{array}$ & $\begin{array}{l}\text { Yes (1); } \\
\text { No (39) }\end{array}$ & $\begin{array}{l}\text { Yes (0); } \\
\text { No }(40)\end{array}$ & $\begin{array}{l}\text { Yes (7); } \\
\text { No (33) }\end{array}$ & $\begin{array}{l}\text { Yes (4); } \\
\text { No (36) }\end{array}$ & $\begin{array}{l}\text { Yes (0); } \\
\text { No (40) }\end{array}$ \\
\hline $\begin{array}{l}\text { Does an } \\
\text { enterprise use } \\
\text { elements (tools) } \\
\text { of ACFM }\end{array}$ & $\begin{array}{l}\text { Yes } \\
(26) ; \text { No } \\
(14)\end{array}$ & $\begin{array}{l}\text { Yes (10); } \\
\text { No (30) }\end{array}$ & $\begin{array}{l}\text { Yes (5); } \\
\text { No (35) }\end{array}$ & $\begin{array}{l}\text { Yes (29); } \\
\text { No (11) }\end{array}$ & $\begin{array}{l}\text { Yes (16); } \\
\text { No (24) }\end{array}$ & $\begin{array}{l}\text { Yes (8); } \\
\text { No (32) }\end{array}$ \\
\hline $\begin{array}{l}\text { Does an } \\
\text { enterprise use } \\
\text { ACPM }\end{array}$ & $\begin{array}{l}\text { Yes (5); } \\
\text { No (35) }\end{array}$ & $\begin{array}{l}\text { Yes (2); } \\
\text { No (38) }\end{array}$ & $\begin{array}{l}\text { Yes (0); } \\
\text { No (40) }\end{array}$ & $\begin{array}{l}\text { Yes (9); } \\
\text { No (31) }\end{array}$ & $\begin{array}{l}\text { Yes (6); } \\
\text { No (34) }\end{array}$ & $\begin{array}{l}\text { Yes (0); } \\
\text { No (40) }\end{array}$ \\
\hline $\begin{array}{l}\text { Does an } \\
\text { enterprise use } \\
\text { elements (tools) } \\
\text { of ACPM }\end{array}$ & $\begin{array}{l}\text { Yes } \\
(22) ; \text { No } \\
(18)\end{array}$ & $\begin{array}{l}\text { Yes (12); } \\
\text { No (38) }\end{array}$ & $\begin{array}{l}\text { Yes (7); } \\
\text { No (33) }\end{array}$ & $\begin{array}{l}\text { Yes (25); } \\
\text { No (15) }\end{array}$ & $\begin{array}{l}\text { Yes (14); } \\
\text { No (26) }\end{array}$ & $\begin{array}{l}\text { Yes(10); } \\
\text { No (30) }\end{array}$ \\
\hline
\end{tabular}

Source: Developed by the authors.

In addition, based on the most frequently stated problems (three problems for each profitable and unprofitable big, medium, and small enterprises), the research has suggested highlighting three key problems of anti-crisis financial and personnel management implementation at the enterprises chosen for the study. Then, they were united in the table (Table 3).

Table 3. Key problems of the implementation and application of ACFM and ACPM at the enterprises of the agricultural sector in Eastern European countries

\begin{tabular}{|l|l|l|}
\hline \multicolumn{1}{|c|}{$\begin{array}{c}\text { Type of an } \\
\text { enterprise/problem }\end{array}$} & \multicolumn{1}{|c|}{ Profitable } & \multicolumn{1}{c|}{ Unprofitable } \\
\hline \multirow{4}{*}{ Big } & $\begin{array}{l}\text { A lack of positive examples of } \\
\text { ACFM implementation; a lack } \\
\text { of effective methods for } \\
\text { diagnosing; problems in } \\
\text { training specialists in anti-crisis } \\
\text { management }\end{array}$ & $\begin{array}{l}\text { The cost of implementation, } \\
\text { problems on rebuilding of } \\
\text { management personnel } \\
\text { structure; a lack of effective } \\
\text { methodologies for assessing the } \\
\text { depth of the crisis. }\end{array}$ \\
\hline \multirow{5}{*}{ Medium } & $\begin{array}{l}\text { Not acceptance by owners and } \\
\text { top managers, a lack of trained } \\
\text { personnel, a lack of firms } \\
\text { providing consulting services } \\
\text { on ACFM. }\end{array}$ & $\begin{array}{l}\text { Not acceptance by owners and } \\
\text { top managers, a lack of trained } \\
\text { personnel, a cost of the } \\
\text { implementation. }\end{array}$ \\
\hline Small & $\begin{array}{l}\text { Not acceptance by owners and } \\
\text { top managers, a cost of the }\end{array}$ & $\begin{array}{l}\text { Not acceptance by owners and } \\
\text { top managers, a cost of the }\end{array}$ \\
\hline
\end{tabular}


\begin{tabular}{|l|l|l|l|}
\hline & $\begin{array}{l}\text { implementation, personnel's } \\
\text { opposition. }\end{array}$ & $\begin{array}{l}\text { implementation, a lack of } \\
\text { trained personnel. }\end{array}$
\end{tabular}

Source: Developed by the authors.

The research has identified a great number of problems on the implementation and application of anti-crisis financial and personnel management at agrarian Eastern European enterprises. It needs the development of a set of ways to address them.

\subsection{Ways to Increase the Effectiveness and Performance of Anti-crisis Financial and Personnel Management at Agricultural Eastern European Enterprises within the Provision of their Stable Long-term Development}

Within solving problems detected during the analysis of the implementation and application of ACFM and ACPM at enterprises in the agricultural sector of the PostSoviet Eastern European countries, it is necessary to:

- increase promotion of the importance of the implementation and application of ACFM for agricultural enterprises by demonstrating positive examples;

- to activate the development of new methods for diagnosing financial crises at agricultural enterprises;

- introduce changes in the training of specialists in ACFM by emphasizing the active attraction of electronic resources and online learning as well as by engaging employees and owners of unprofitable agricultural enterprises in the educational process;

- activate and reform the state and municipal aid (financial, consulting, and informative) for unprofitable agricultural enterprises, especially MSE, to implement and use ACFM and ACPM;

- change professional training and focuses on advanced training for employees of Eastern European agricultural enterprises to implement anti-crisis personnel management;

- develop and introduce strategies of anti-crisis financial and personnel management for Eastern European agricultural manufacturers from the PostSoviet space taking into consideration profitability and losses of their operation as well as sizes of economic entities.

The implementation of the set of ways introduced above will allow to increase the effectiveness and performance of anti-crisis financial and personnel management at agricultural enterprises of the Post-Soviet countries in Eastern Europe within the provision of their stable long-term development.

\section{Discussion}

The share decrease of unprofitable enterprises in the agricultural sector of economies of Eastern European countries in the Post-Soviet space has a great potential for accelerating the growth of both agricultural production in these countries and their 
economic systems. Under these conditions, agricultural manufacturers from Eastern European countries should pay special attention to the implementation and active application of anti-crisis financial and personnel management and its tools. Anticrisis financial and personnel management is emphasized to be key factors for development securing of agricultural manufacturers under the modern terms of economies operation of Eastern European countries. The data stated above need scientific research and verification of a set of hypotheses.

While doing it, the first, the third and the fourth hypotheses of the study were proved during its conduction. The second hypothesis was denied due to the fact that unprofitable agricultural enterprises have a decisive influence on the development of the agricultural sector and a significant impact on the development of Eastern European countries' economies.

Based on the data provided above, the aim of the research outlined at the beginning of the work was reached. The key value of the article is the developed set of ways to increase the performance and effectiveness of ACFM and ACPM at Eastern European agricultural enterprises. In this context, the research has allowed to provide some restrictions in the implementation of the results of this article, namely: the necessity for more detailed analysis of the agricultural production in all countries of the Post-Soviet space; the necessity in forming a set of activities for the implementation of ACFM and ACPM at Eastern European agricultural enterprises. At the same time, the restrictions stated do not demean the scientific and practical value of the article. To a greater extend, they characterize perspectives of further scientific studies.

\section{Conclusion}

Anti-crisis financial and personnel management is becoming increasingly important for securing a stable growth of agricultural enterprises in Eastern European countries. At the same time, the implementation and application of ACFM and ACPM are facing a great number of problems at such enterprises. It decreases their effectiveness and performance, and it is regarded as a key de-stimulating factor for the agricultural sector and national economies of Eastern European countries in the Post-Soviet space. The information provided above indicates the appropriateness of scientific studies in this direction.

The article has proved the increasing role of the agricultural sector in economies of Eastern European countries as well as a significant negative influence on it by unprofitable agricultural enterprises. While doing it, the study has assessed the implementation of ACFM and ACPM at such enterprises and main problems in doing so. In addition, the research has developed a set of ways to increase the effectiveness and performance of the implementation and application of ACFM and ACPM in the agricultural sector of Eastern European countries. 
The practical implementation of the article's proposals and conclusions is to be regarded in the context of their importance for the share decrease of unprofitable agricultural enterprises and accelerating the development of the agricultural sector in Eastern European Post-Soviet economies.

The perspectives of further studies, which are based on and implement scientific results of this research, are the development of an effective set of measures to activate the application of ACFM and ACPM in the agricultural sector of countries in East Europe.

\section{References:}

Bahadir, S., Unlu, A., Kapucu, N. 2008. Perspectives on crisis management in European Union Countries: United Kingdom, Spain and Germany. European Journal of Economic and Political Studies, 1, 19-45.

Bański, J. 2018. Phases to the transformation of agriculture in Central Europe - Selected processes and their results. Agric. Econ. - Czech, 64, 546-553.

Batorski, J. 2011. Fragmentation of crisis management in an enterprise. Serbian Journal of Management, 6, 283-286.

Chryniewicz, L., Kyryliuk, D., Wojtaszek, M. 2016. Key factors increasing competitiveness of agriculture in Ukraine. Roczniki Naukowe Stowarzyszenia Ekonomistów Rolnictwa i Agrobiznesu, 1(18), 35-42.

Csáki, C., Kray, H., Zorya, S. 2006. The agrarian economies of Central-Eastern Europe and the commonwealth of independent states: An update on status and progress in 2005. Working paper no. 36. World Bank Group, Washington, D.C.

Dudareve, A.B. 2017. Peculiarities of anti-crisis management in agriculture. The Journal of agricultural development and social policy, 3(15), 1-5.

FAO. 2018. Review of Agricultural Trade Policies in the post-Soviet countries 2016-17. Available at: http://www.fao.org/policy-support/resources/resourcesdetails/en/c/1152540.

FAO. 2019. World Food and Agriculture. FAO Statistical Yearbook. Food and Agriculture Organization of the United Nations, Rome, Italy.

Federal State Statistic Service of the Russian Federation. 2020. Statistical information. Available at: http://www.gks.ru

Gurtner, B. 2010. The financial and economic crisis and developing countries. International Development Policy, Revue internationale de politique de développement, 1(1), 189213.

Kalinichenko, A.V. Shmygol, Yu.V., Kostoglod, K.D. 2010. Forecasting with the help of regression function. The Journal of Kharkiv Petro Vasylenko National Technical University of Agriculture, 104, 10-16.

Kimhi, A., Lerman, Z. 2015. Agricultural transition in post-soviet Europe and Central Asia after 25 years. IAMO, Halle, Germany.

Lerman, Z. 2009. Land reform, farm structure, and agricultural performance in CIS countries. China economic review, 20(2), 316-326.

Narkevich, L.V. 2017. The formation of effective sanation mechanisms in the system of anticrisis management of an agricultural organization. The problems of economy, 2(25), 104-115. 
National Bureau of Statistics of the Republic of Moldova. 2020. Statistical information. Available at: http://www.statistica.md/index.php?l=ru.

National Statistical Committee of the Republic of Belarus. 2020. Statistical information. Available at: http://www.belstat.gov.by.

Petrick, M., Weingarten, P. 2004. The role of agriculture in central and Eastern European rural development: Engine of change or social buffer? IAMO, Halle, Germany.

Shashyna, M.V., Zakharchenko, O.V., Darushyn, O.V., Buryk, Z.M., Shpinkovska, M.I. 2018. Agroindustrial complex in the Eastern European countries in the context of sustainable development. The Journal of Social Sciences Research, Academic Research Publishing Group, 5, 549-562.

State Statistics Service of Ukraine. 2020. Statistical Information. Available at: http://www.ukrstat.gov.ua.

Usikova, O.M. 2019. Anti-crisis financial management of agricultural enterprises in the current context of management. Actual Problems of Innovative Economy, 1, 49-55.

Zakharchenko, O.V., Eremina, A.R., Ushakov, D.S., Odintson, O.M., Mylnichenko, S.M. 2019. Management of reputation risks at the agricultural enterprises of Eastern Europe as a component of increasing their competitiveness. Journal of Reviews on Global Economics, 8, 859-872.

Zhigang, L., Hongqi, C. 2015. Strategy of enterprise crisis management in the information age. International Conference on Management Science, Education Technology, Arts, Social Science and Economics. Atlantis Press, 720-722. https://doi.org/10.2991/msetasse-15.2015.159. 